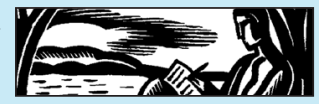

\title{
Youthful Death and Melancholia: The Case of Rupert and Mary Brooke
}

\begin{abstract}
Alisa Miller
Royal Military Academy Sandhurst

\section{ABSTRACT}

This article considers how Mary Brooke, the mother of the poet-soldier Rupert Brooke, managed her mourning and melancholia in the wake of the death of her sons in the First World War. It briefly considers how Brooke's death and poetry framed and, to some extent, predicted his popularity during and after the war. It goes on to explore how Mary Brooke constructed lasting literary and physical monuments to her son, which reframed his public life narrative and reflected her own culturally ingrained philosophical and aesthetic preferences. It examines how her experience reflects established and changing practices with respect to women and public death, and the elements that made her case exceptional. Finally, it places her story in the wider history of European melancholia as it relates to war, grief and creative expression.

Keywords: mother, mourning, melancholia, poet-soldier, Rupert Brooke
\end{abstract}

\section{INTRODUCTION}

Mary Brooke, née Ruth Mary Cotterill (1851-1931), the mother of First World War poet-soldier Rupert Brooke (1887-1915), had been born into a Victorian Britain that was intensely concerned with codifying the rituals of public and private death. This was a period that saw a rise in the 'funeral competition' enacted by elites, wherein often huge amounts of 
money were spent to honour and celebrate the dead, creating a spectacle of grief. ${ }^{1}$ The most famous and extreme example was offered by Queen Victoria in her mourning for Prince Albert from December 1861 until her death in January 1901, which in turn influenced how mourning was expressed in Britain in everything from women's dress to funeral rituals ${ }^{2}$ - already established, and criticised, as big business. ${ }^{3}$ These commodifying practices, in turn, placed pressure on the middle and working classes to find ways to perform rituals that expressed their grief, but on a budget. ${ }^{4}$ They governed everything from funerals and memorials to full mourning attire; the latter became increasingly elaborate and expensive across the second half of the nineteenth century, before declining in the years leading up to the First World War. ${ }^{5}$ In some ways, the mourning dress made women in Europe, who had traditionally 'played little part in grand funerals for men', more visible. ${ }^{6}$ When it came to the apogee that was the Victorian funeral-what John Morley had called the 'quintessence of sentiment and gentility' — they increasingly became central if often silent figures in the public performance of death rituals.

An intelligent and astute student of social and cultural shifts, Mary Brooke-who had grown up in Stoke-on-Trent, where her father was incumbent of the parish-would have been aware of the progression of mourning practices, and would soon have cause to revisit and deploy them for use in her own life. In 1915, she lost both of her surviving sons to the First World War in rapid succession; her eldest son had died of illness prior to the war, as had her husband. Once wife of a House Master at Rugby School, overseeing a household teeming with boys, she now found herself living alone in a small terraced house. She faced a future heavy with grief and loneliness as well as the quotidian financial struggles that so often dominated the lives, certainly of working-but also of middleclass widows who were 'especially vulnerable to the material implications of death'.

Although, to some extent, Mary Brooke's experience of bereavement was perhaps more public than many others, it allows us to interrogate ideas about how grief and melancholia were managed during the First World War. She watched as her middle son Rupert Brooke attained celebrity status in death: his life and death became a parable for national loss and, as a fallen soldier, a focal point for nationalist sentiment. ${ }^{9}$ This conferred upon her a public status, some agency, and greater financial security. She tried, and ultimately partly succeeded in, asserting some familial authority over the management of his estate and public life narrative. She did so while contending with her own profound sense of personal loss and isolation in a period when the grief of women was often generalised, sentimentalised, pathologised and finally dismissed. She turned her 
melancholia into something active, even creative; or as W.G. Sebald had defined it, a form of resistance. This framing of melancholia, articulated in Sebald's Die Beschreibung des Unglücks, runs counter to the notion that the state of being is characterised by paralysis or langour. It provided an epitaph for the 2017 ERC-funded exhibition Melancholia: A Sebald Variation, curated by Lara Feigel and John-Paul Stonard, which explored the relationships among art, writing, creativity and war that this article considers through the lens of gendered melancholia. ${ }^{10}$

In terms of experiencing the loss of a child or children as a result of the First World War, Mary Brooke was, of course, by no means unique. Mothers across Britain and the world had to contend with the early, often violent death of their children. Where possible and desirable, they engaged in life and death writing in order to make sense of their losses. Mary Brooke provides a case study of the particular melancholia wrought on individuals-and specifically women - and societies in the wake of the conflict (as well as those spanning the twentieth century more generally) that compounded individual and collective death and grieving. Her story also provides an example of the complex ways in which engagement with public and private memorials-physical and written-operate as forms of cultural reckoning with death and mourning across time, as cycles of violence repeat themselves and people attempt to make sense of grief and loss.

In the wake of the First World War, the many peoples around the world who had been drawn into the conflict experienced a sense of dislocation. In Europe, this manifested itself as a sustained melancholia as societies grappled with the scale of the destruction wrought on lives and the land. Although its domestic material damage was limited relative to other combatant nations, British culture was also profoundly shaken by the encounter with mass violent death, encapsulated in the idea of the 'Lost Generation'. This was experienced more disparately and grimly by families and communities, day after day, contending not only with the sacrifices of the war dead but with the survivors, marred by physical and mental injuries, social and economic insecurities, and the ruptures associated with the great pandemics that raged across the world, spread by returning armies and refugees.

At the same time, the First World War had shifted institutional relationships and cultural practices: much power had been turned over from the family to the state. Attitudes towards death and mourning in the Victorian period had evolved to become more elaborate events, at least for those who could afford it. During the First World War, a more compressed, decisive if not unprecedented shift in philosophy occurred, with the war dead coming to belong to the nation as much as to their relatives and 
communities. Hence, who could assert control over the life narratives of the dead-and in what media-took on an expanded meaning. Debates about provisions for the casualties of war moved up the national agenda as issues like pensions became more prominent in political discourses. ${ }^{11}$ Casualties numbered not only the dead but the returning soldiers, mothers, widows and orphans, creating intertwined networks requiring material, psychological, and even spiritual support. And yet the many examples of 'fictive kinship' that emerged in the period were not sufficient in themselves to counter the prevailing melancholia, expressed in a variety of life writing forms by the war's perpetrators, victims and survivors. As Jay Winter argued, the conflict created both a space and a need for practical as well as artistic expressions capable, at least in part, of reckoning with the damage it had caused and its weight of cultural memory. ${ }^{12}$

In the wake of her poet-soldier son's death, Mary Brooke confronted the complexities of balancing personal grief with public interest in Rupert Brooke, the national icon. Understandably, she lived in an atmosphere infused by a melancholia, which initially paralysed her: in 1917, she had her son's portrait medallion (cast in a Chelsea studio to resemble Sherril Schell's 1913 profile photograph of the poet) propped up in the hall, later reflecting that prolonged 'looking at it was almost too much for me, and I was glad when it went'. ${ }^{13}$ But ultimately, she found ways to channel her grief into creative enterprises, fulfilling Sebald's concept of melancholia-particularly when it arose in response to war's devastationsas culturally productive. ${ }^{14}$ In this article, I will show that Mary Brooke constructed lasting literary and physical monuments to her son, which reframed his life narrative and reflected her own culturally ingrained philosophical and aesthetic preferences.

\section{LIFE WRITING AND PUBLIC DEATH}

When the aspiring 23-year-old poet, Rupert Brooke, published his first book of Poems in 1911, the gossip at Rugby School was all about how shocking and uncouth it was. One of the other housemaster's wives expressed her sympathy for his poor mother at the 'shame that Rupert had brought on her and the school. ${ }^{15}$ Handsome, talented and-through his overlapping networks of friends-well-connected, Brooke was passing through a difficult period in his life. Romantic affairs fizzled out, and he could not seem to settle in a career.

Between the publication by Sidgwick and Jackson of the Poems and the outbreak of war in August 1914, Brooke would travel to the Continent, the Americas and the South Seas, capturing his impressions in letters, poetry and prose. He also made friends with writers and editors, supplementing 
his already impressive cadre of admirers. In the spring of 1912, he penned the much-loved and often-quoted poem 'The Old Vicarage, Grantchester', written in a café in Berlin. After Brooke's death from sepsis on the eve of the invasion of Gallipoli, the Cambridgeshire countryside sentimentally described in the poem provided one of the many landscapes in which the idealised figure of the poet-soldier was imaginatively situated by influential and aspiring life writers producing diaries, letters, (auto) biographical poetry and prose throughout the war period.

His death from a blood infection (as opposed to in action) on 23 April 1915 came as a shock to his family and friends. Yet some immediately saw his potential as a romantic figure-an emblem of voluntary youth offering themselves as sacrifices for Empire, country, and honour. Brooke had, in some ways, anticipated this; what came to be known as his 'War Sonnets', published first in the small literary periodical New Numbers, became a runaway success. This was, in part, because the poems seemed to condense a sentimental, heroic vision of the war just as the scale of the disaster it posed to persons and communities started to dawn on leaders and citizens alike. They also seemed set up by their author to frame his 'perfect' sacrifice offered in a state of 'serenity' ${ }^{16}$ to confirm its voluntary nature, and to elevate all of the war dead: in Brooke's words, 'dying, has made us rarer gifts than gold'. ${ }^{17}$

Winston Churchill, architect of the failed Gallipoli landings and then First Lord of the Admiralty, published an influential obituary in The Times on 26 April 1915. ${ }^{18}$ In it, he praised Brooke's unique just-audible 'voice' speaking to his 'self-surrender'. Churchill, aware of mounting casualties, responsibility for whom might at least in part be laid at his door, was careful to emphasize that the poet-soldier, like others in Britain at this time, volunteered to die. He also fixed on the trope of Brooke's 'classic symmetry of mind and body. ${ }^{19}$ Newspapers across the country and later the world echoed Churchill's praise, acknowledging the 'radiant, perfectly poised story of Rupert Brooke', ${ }^{20}$ who in life and especially in death became 'A meteor flag of England'. ${ }^{21}$ Established and emerging poets alike wrote tribute poems and essays; the classicist Gilbert Murray concluded that 'I cannot help thinking that Rupert Brooke will probably live in fame as an almost mythical figure [...] Among all who have been poets and died young, it is hard to think of one who, both in life and death, has so typified the ideal radiance of youth and poetry'. ${ }^{22}$ From May 1915 and extending throughout the war years, in high and popular cultures of the war, Brooke retained his position as 'England's Poet-Soldier'. ${ }^{23}$

Sidgwick and Jackson had taken a chance on the young poet in 1911. From 1915 onwards, they reaped the rewards, trading on Brooke's national celebrity: 1914 and Other Poems would sell over 100,000 copies in Britain 
alone between 1915 and $1920 .{ }^{24}$ They continued to publish his back catalogue of poetry and prose throughout the war, as they and Marsh-aided by a number of sympathetic champions-successfully managed his literary estate, extending and amplifying the range of the myth of the poetsoldier for and with the help of readers across the world.

Included with the volumes and, in many cases, the associated articles and reviews, were photographs of the handsome poet looking romantic and very much alive, forever suspended in a pre-war state of rumpled, bohemian youth. Looking at the photographs, taken by Sherill Schell in 1913, the war that was brutally and graphically consuming the actual youth of the nation seemed very far away. In Brooke, readers could admire the preserved beauty of the Lost Generation that the 'War Sonnets' elevated and glorified. When abstracted, his seemed the perfect life and death for the dislocating cultural moment..$^{25}$

Somewhat absent as a distinct and identifiable figure from the hagiographies was the poet-soldier's mother, Mary Brooke, whose grief was compounded when, in June 1915, her youngest son, Alfred, was killed in France. She had lost her younger sons at a moment when cultural practices around death were shifting - a process that was reconfigured by the First World War. In the lead up to the conflict, death rates of children and in particular young adults declined rapidly. This meant that, when mass death arrived, it was at least for upper- and, to some extent, middleclass families shocking. While throughout history, families of all classes might have experienced the death and ensuing bereavements stemming from infant deaths, Pat Jalland writes that ' $[\mathrm{t}]$ he only comparable loss for Victorian parents was the death of an adult child by violence or suicide or far from home-[of] all deaths which were identified as "bad" deaths [...] those few had a marked tendency to promote chronic grief, which was otherwise rare'. ${ }^{26}$ Julie-Marie Strange offers an alternative perspective to how mourning was codified from 'above'. She explores the extent to which class operated in this period, with the war unmooring 'certainties concerning ownership of the corpse'. Poorer families had greater experience of responding to practical necessity by turning over their dead to be buried in public graves. Now elites found themselves likewise 'confronted with the dispossession of the dead'. ${ }^{27}$ Mary Brooke experienced this dispossession in a variety of ways: not just physically turning over her son's body to the state, but also his life narrative to various interested parties, state and commercial. With respect to the management of Rupert Brooke's posthumous myth, she would find herself in uncharted territory: attempting to assert some control over memorials that others saw as cultural, collective and allegorical, as opposed to familial reliquaries. 
Some inherited Victorian forms guiding the public management of grief held, offering Mary Brooke potential inspiration and, more broadly speaking, providing consolation if not resolution of individual suffering or collective loss. These included conventions around literary epitaphs and physical memorials that invoked general, as opposed to specific religious beliefs and practices, and the civic value of sacrifice for the nation. The growing awareness of the war's brutal practice and scale meant that there were no entirely appropriate or resilient parables to turn to-although some, like Sigmund Freud, in his 1917 analysis of the interplay between mourning and melancholia, tried to articulate an 'economical characterization of pain'. ${ }^{28}$ As Winter contends, with respect to war memorials made manifest in various forms-from poetry and literature to monuments and dress-the 'modernist' and 'traditional' forms of imagining war were in evidence long before the Armistice, and they were never as distinctive as apologists on both sides suggested'. ${ }^{29}$ In her experience of life and death writing, Mary Brooke would find herself under pressure from these different factions, even as she also identified ways to assert her perspective.

\section{ESTATE}

Memory—family and national—is always contested territory, especially when it comes to war and ideas of youthful death in service of the state. In any nation, at any time, debates rage about how the lives of the war dead are written, and who may speak on their behalf. This is especially the case when societies begin to question whether or not the political ends pursued by nations, and the 'peace' they secure, are worthy of the individual and collective sacrifice. It is also particularly fraught when long-held assumptions about who retains authority over the treatment and guardianship of the dead begin to shift, as was the case during and after the First World War with respect to women's roles in public life and death.

Rupert Brooke was changeable in his views; he always had a complicated relationship with women, none more so than his mother. His vacillating stance depended in part on where he stood with respect to a given love affair or romantic disappointment. Writing to Frances Cornford in June 1914, he laid out his (then) current position, rather starkly, given his former association with Fabian Socialism and his friendship with a number of strong, modern women:

No, Sir. I'm not insulting women. I adore them. I'm insulting feminists. I loathe them-that is to say I loathe the feminist part in many otherwise nice people which spoils them much and other people and things almost more. 
And I $d o$ assert that women are not very good at certain kinds of governing. Just as I assert that men are not very good at suckling babies. ${ }^{30}$

He loved and respected his mother, nicknaming her 'the Ranee' to his 'Rajah' as a teenager. ${ }^{31}$ However, they did not always get on. Mary Brooke found him frustrating: when he told her in 1914 that, rather than settling into a career, he planned to make an extended trip to the United States, she replied: 'Why are you so unsatisfactory? Is it my fault'??2

Perhaps this influenced his decision to appoint his close friend, Edward Marsh, to manage his affairs, to whom he wrote in March 1915, from off the Greek coast: 'I suppose I must imagine my non-existence, and make a few arrangements. You are to be my literary executor'. He did, however, make sure that his mother would have some role: 'But I'd like mother to have my MSS till she dies-the actual paper and ink I mean-then you [...]'. Generously, he also willed some money to his fellow poets from the New Numbers periodical, where he had first published his 'War Sonnets. ${ }^{33}$ This would prove a windfall for them in the wake of the success of Brooke's myth, associated poems and his other posthumous publications.

As loyal as Marsh was to Brooke, and as much as he understood the literary and political networks that enabled his rise to symbolic fame, his mother had the greatest personal interest in preserving his reputation. She maintained a broad correspondence with friends and those wishing to offer their condolences, inheriting elements of her son's broad literary and political networks who wished to pay their respects and offer up impressions of the poet-soldier. However, she had generally been excluded from the process of public memorialising, first with respect to the reprintings of his poems that Marsh and Sidgwick made available to various publications. She was also often omitted from the many obituaries and articles that appeared across the country and the world throughout the war years. And, finally, Marsh kept her, for quite some time, excluded from discussions of the literary estate and its relationship to the emerging Brooke myth, which he did not believe she could ever fully grasp or manage.$^{34}$ As such she was left largely incapacitated in an official sense, cut off from direct access to, or influence over, her son's celebrity.

This arrangement suited Mary Brooke in the immediate aftermath of Rupert's and Alfred's deaths, when she was left to deal, largely on her own, with her grief. On 18 June 1915, the Rugby Observer noted the double loss in an obituary for Alfred Brooke, which also reiterated his poet-soldier brother's life, talent and death: 'By his [Alfred's] death, Mrs Brooke has lost her only surviving son. Two of her sons have died in service of their country [...] the heartfelt sympathy, not of Rugby only but of the whole country, will go out to her in her terrible bereavement. ${ }^{35}$ While this 
local article was more personal in that it acknowledged her compounded bereavements, the majority of the obituaries and articles made reference not to Mary Brooke or 'Mrs. Brooke', but to the mother of Rupert Brooke. She was now presented not as a specific, grieving person but as an archetype: the nation's mourning mother, as Brooke was the nation's melancholic sage.

Expressions of condolence came in from his friends, but also from members of the public. Laurence Binyon, who wrote the much-quoted poem 'For the Fallen', sent Mary Brooke an unsigned tribute poem inscribed to the poet-soldier in 1917. He hoped to console the poet-soldier's mother, asking her to 'forgive my liberty' but 'Your son is a radiant memory to me'. It echoed lines from panegyrics published in the national and international press in response to the posthumous publication of Brooke's poetry and prose: 'There was wrong / Done, and the world shamed. Honour blew the call, / And youth's high answer was a[s?] natural / And quiet as the needle's to the pole'. ${ }^{36}$ Channelling the public writing of Brooke's life and death, in Binyon's private poem, he becomes the nation's 'youth', his death fated and modest, redeeming the world's 'Honour'.

As each authorised and unauthorised or spontaneous poem, article, address or memoir by or about Brooke appeared, he became something unreal, an abstraction. As a result, Mary Brooke was denied a large measure of control that she, as his mother and sole surviving immediate family member, might have had over her son's public myth. She was not alone in this experience as a mother of a soldier sacrificed in war living through a period when the meaning and legacy of motherhood and death for the nation became much debated, nor in simultaneously desiring that her son be honoured and recognised, but without becoming a public possession. This remains fraught territory given the complex moral implications of death in service of the state, the rights and desires of families to reclaim their dead, and the raw, painful political debates that often follow in the wake of conflicts.

Such debates cross cultural, territorial and temporal boundaries. At the other end of the twentieth century, in Minsk in 1993, the writer Svetlana Alexievich, who would go on to win the Nobel Prize for Literature, was put on trial. One of the mothers of the soldiers whom she had interviewed for her book, Boys in Zinc, about the USSR's war in Afghanistan, testified in the trial about why she had wanted to speak to Alexievich, and why she felt betrayed by what Alexievich had done with her account in the published version of the book, which was a compilation of diaries, letters and interviews - a chorus of voices- that the author edited into a single non-fiction text. After I. S. Galovneva's son was killed, she testified in court that she turned in on herself, away from any public tributes or 
attempts at commemoration: 'I lay flat on my back for a month. I didn't want to hear anyone. Everything in our home was switched off. I didn't open the door to anyone'. Alexievich is the first person she allows in, and when she asks her to participate in the narrative project, Galovneva implies that she is simply happy to talk to someone, about her life and her son: '[...] we talked. I told her about my life because I was feeling miserable. I was just stuck inside four walls, down on my knees'. ${ }^{37}$ Although she agrees to be recorded, she then claims that she did not understand that the elements she relayed about her own story, as the mother of a lost son, would be published; she claims that she gave Alexievich her son's diary, expecting her to quote from it and print it without any editing.

Later questioning in the trial reveals that Galovneva's objections had to do with Alexievich's general argument in the book, about what she viewed as an unjustifiable, criminal war, and her concern that, because it was published abroad, it would be de-contextualised, misunderstood and misused as a propaganda weapon. However, she objects to Alexievich working as an active editor with creative license over the selection and framing of the primary material, and of her loss of control over her son's life and death in the war, to a public — and indeed an internationaldebate over the war's rectitude..$^{38}$

Like Galovneva, as the mother of a son killed by war, Mary Brooke felt that she ought not to be expected to fully hand over, and should be consulted about the development and-where possible-use of, Brooke's posthumous life narrative. Yet as an older, grieving woman, she struggled to assert herself. In the years following Brooke's death, in London, if a publisher or newspaper required permission for something, Marsh was the official point of reference, and hence, became a kind of exclusive source. No one immediately thought to write to Mary Brooke, alone in Rugby, like the initially near-incapacitated Galovneva, 'brooding over' accounts of her son's death with 'morbid intensity'. ${ }^{39}$

Mary Brooke's and Edward Marsh's fight for control over Brooke's public image crystallized around the latter's extended attempts to put down on paper a kind of official 'Memoir' for his friend that would speak to his many personal and literary virtues, while attempting to correct some of the more abstracted elements of his hagiography. Mary Brooke collaborated with Marsh on the project, providing accounts from her correspondence. For both, it was a difficult task. Marsh explained his approach: "Literary merit", in the humble sense in which I am using the words, is not a scholar's fetish, or a mere inessential ornament; it is the quality which makes the difference between a book that will do, and a book that won't'. ${ }^{40}$ She wrote back, furiously-invoking, somewhat cruelly (given Marsh's long devotion to her son) her family connection-that her views 
about which aspects of her son's life and which friends' testimonials ought to be included to build up a composite, impressionistic biography, were being sacrificed to Marsh's vision for the book: 'You couldn't bear me taking my stand as his mother, ${ }^{41}$ Exasperated, Marsh wrote-also cruelly-to the sympathetic Frank Sidgwick (of Brooke's publishers Sidgwick and Jackson), who was also dismissive of her attempts to get involved: 'How Rupert could be produced by a woman without sense of humour or beauty, and narrow to that degree, I shall never understand'. ${ }^{2}$

Publicly, when the Memoir appeared in July 1918, they maintained a unified front. Mary Brooke's short introductory note offered an air of family approval, even though technically, given that Marsh was still in charge of the estate, it was not required. In it, she praised her son's literary executor: 'I cannot speak strongly enough of the ability and the loving care that Mr. Marsh has brought to the work', ${ }^{4}$

Marsh had, to some extent, mis-calibrated literary England's appetite for the 'Memoir'. A new generation was starting to take hold of the critical discourse, and some influential readers and reviewers were sceptical, if not openly hostile to his efforts. In a piece for the Times Literary Supplement, Virginia Woolf characterised it as another form of entombment. ${ }^{44}$ The Cambridge Review argued that it existed only so that 'the legend of Rupert Brooke' could be 'magnificently endorsed', ${ }^{45}$ and Oxford Magazine dismissed its 'atmosphere of eulogy and thanksgiving' ${ }^{46}$

Mary Brooke's audience was, perhaps, older and to some extent broader, more popular and made up of readers who believed in the virtues of the ideal of the poet-soldier: sacrifice, patriotism and the glory of the dead. Her objectives in involving herself in the 'Memoir' also differed from Marsh's. She worked to preserve a glowing, youthful, ever-innocent vision of her son in public, and to maintain the vigil of the grieving mother in private. Finally, she aimed to wrest back some control of the estate and myth for herself by finding ways publicly to articulate and preserve a sense of creative melancholia.

\section{MEMORIALS}

Samuel Hynes, writing of post-war Britain, traces how Armistice Day celebrations, the local and national ceremonies of remembrance, and the unveiling of public monuments and national cemeteries, worked as cultural expressions that were meant to preserve the Lost Generation; these also made their way into the publishing world. Writers and editors participated in a literary 'monument-making' in which older men who had not fought, and to an extent younger men who had survived, produced artistic and literary works of remembrance centred around key establishment 
themes: 'Service and Sacrifice, Empire, the Great War, Patriotism'. These were asserted, Hynes argues, 'not only in the face of the emerging contrary tradition, but of the known fact of the war, and the numbers of the dead'. 47

For Mary Brooke, 'Service and Sacrifice' and 'Patriotism' were words and ideas that had sanctified and continued to frame her son's death and public reputation-and should continue to do so in perpetuity. It did not matter that a counter-literary tradition-one that was, in some cases, led by her son's close friends from Cambridge and the Bloomsbury circle-was emerging that was more critical of the war, and of the way the war dead were invoked in British culture as patriotic stereotypes. ${ }^{48}$ Hynes characterises literary memorial traditions at the time as aiming to 'commemorate not so much a number of individuals as one generation of a class. And they do something else: they preserve-artificially, anachronistically, like objects in a museum-the spirit in which these men went to war', as opposed to the contested post-war period. ${ }^{49}$

However, as Mary Brooke-an educated, middle class woman with established, traditional Liberal views who had come of age in late Victorian Britain-might have argued, wasn't this fixing of an ideal of traditional, heroic, patriotic sacrifice the very thing that Brooke had captured so succinctly and poetically in his five 'War Sonnets', for which he had been highly praised? Wasn't this what he meant when he wrote in 'The Soldier', 'If I should die, think only this of me'? ${ }^{50}$ Her sons had died early in the war, in 1915; her specific tragedy put her at odds with the majority of families at the end of the war who, as Adrian Gregory has written, had understandably complex feelings as the vast majority of soldiers (eventually) made their way home to communities laden with contradictory emotions of relief, escape and bereavement: 'The fortunate majority, and it cannot be stressed often enough that the majority were fortunate, could not help feeling a certain unease about their (the survivors of the war dead A.M.) reactions,.$^{51}$ It was this unease that fed into post-war commemorative cultures, which were based less on direct family loss and had more to do with an abstracted desire to recognise the loss of others. ${ }^{52}$

During the war, from May 1915 and for years after, Mary Brooke kept track of what was written about her son, cutting articles from newspapers and arranging them in albums. Then, she turned to the idea of a physical memorial. Like many who worked to create sites wherein the 'dead were symbolically brought home', ${ }^{53}$ she likely longed to establish a connection to her son's distant grave ${ }^{54}$ by drawing on what Lara Feigel has described as melancholia's simultaneously contemplative and creative power; $;{ }^{55}$ she started with Rugby Chapel. In February 1916, a committee was formed, responsible for commissioning a plaque to be placed at the school, bearing 
a carved replica of Sherill Schell's profile frontispiece from 1914 and Other Poems-one of the most widely circulated photographs taken of Brooke before the war. Mary Brooke was not an official member of the committee, but she found a way to assert herself through Robert Whitelaw, a close friend and then headmaster of Rugby School. Working through him, she helped to select and order the quotations from her son's War Sonnets that made up the memorial tablet's inscription.

Further afield, when it came to constructing a permanent memorial to replace the simple cross sitting atop Brooke's gravesite at Skyros, she initially allowed Marsh to correspond with the British legation, and subsequently Ambassador Elliot in Athens, on her behalf. Unlike decisions concerning the literary estate-which owing in part to their rapidity were often concluded before she could assert her opinion-the pace of correspondence with officials in Athens enabled her to carve out a space for herself, and largely to control the process. As the poet-soldier's mother, it made sense that she would manage the gravesite of her son, however famous he had become.

Mary Brooke chose almost everything, from the type of marblewhite, conveying a pronounced purity-to the shape of the tomb. ${ }^{56}$ The resulting memorial was solid and traditional: a simple white block, completed in June 1917. Eventually a Gothic-inspired fence was placed around the site, ostensibly designed to keep out the island's animals, and eventually useful in controlling tourists visiting Brooke's grave-a phenomenon reported on by newspapers periodically throughout the 1920s and 1930s.

Playing on one of the established strands of the myth of the poetsoldier, she decided that the memorial should implicitly acknowledge its Classical location, even as she drew a line from Skyros to Rugby. She gave orders that Whitelaw's stanza from the Chapel memorial, entitled 'R. B.', should be translated into ancient Greek. The inscription read as follows:

\footnotetext{
Dear to the Graces we knew thee, thy life long, dear to the Muses:

Ah but-while valuing these, valuing Liberty more,

Gladly thy choice thou madest, to fight for her.

Now, we salute thee:

Lovely wert thou, and thy songs lovely-and lovely thy death. ${ }^{57}$
}

The final line reflected ingrained melancholic and Romantic tropes, as well as an attempt to ascribe meaning to an early death. Mary Brooke's idea of an epitaph expressed in traditional themes and language Victorian ideals of remembrance, celebrating a death that rewarded those who sacrifice themselves, by 'choice', to noble and patriotic ends. She believed in the redemption accrued by what she viewed to be Brooke's final, moral act: dying in service of the ideal of 'Liberty'. Her choice of epitaph also 
speaks to the more conflicted aspect of the Victorian-influenced genre; the language might be archaic but there is no reference to the afterlife.$^{58}$ Her endorsement of the Whitelaw memorial also reveals how thoroughly she had come to accept other writers' and the reading public's ennobling of her son's talent and beauty as a recast classical hero: 'dear to the Muses'. ${ }^{59}$ She draws on this as the appropriate vein in which to frame her son's death in war and burial in Greece-what John Morley has written about in the Victorian period as the vision of the 'stately Claudian landscape', ruled by 'stoicism, not hope' and 'classical resignation' set within a landscape of 'sylvan groves, and antique echoes'. ${ }^{60}$

As profits from the sale of her son's works accumulated, so Mary Brooke's financial situation improved: she was exceptional in having an international, yet still privately commissioned, monument constructed during the war. She received extensive cooperation and special attention from sympathetic senior officials at the British Embassy in Athens. In June 1915, the Ambassador wrote to Marsh: 'I have been much struck by the specimens of Rupert Brooke's poetry which have been published in the papers since his death, and feel deeply that his loss is greatly to be deplored. ${ }^{61}$ This appreciation of the celebrity poet resulted in additional attention for his mother.

Two years later, when it was time to ship the marble for the tomb, she paid for an agent to accompany it and ensure that all went according to plan. From Piraeus to Skyros, the tomb went by way of a British warship. ${ }^{62}$ Ambassador Elliot again interceded in helping to find banks capable of dealing with the required foreign transactions. ${ }^{63}$

With the memorials and epitaphs to her son, Mary Brooke, in some ways, succeeded in conflating two distant sites: the Rugby Chapel and the Skyros hillside. Through her influence, she ensured that both memorials reflected the mythical version of her son, established through all that had been written in the newspapers and in literary memorials, rendering both the proximate Chapel and the far-off Greek shrine as representative of a particular strain of middle class, public school 'Englishness' as they could possibly be. The memorials also reflected her framing of her son's death. The Skyros memorial made use of both a local and an internationally famous site: sitting atop land owned by the monastery of St. George who held vigils of instruction there for local shepherds, it would serve as a point of pilgrimage throughout the twentieth and into the present century for admirers of Brooke's legend and poetry.

Mary Brooke was an exceptionally unlucky mother of two sons who were counted among the war dead. That said, as the mother of England's poet-soldier she was also shown a level of deference that was not extended to many others who had lost sons and daughters to the war when it came 
to memorialising them. In contending with the sheer number of its citizens buried on the Western Front, let alone globally, British officials determined that the state must take over. For the most part, the bodiesat least of those whose families could not assert enough influence or pay to have their bodies repatriated-would remain where they were. Their grave markers would be standardised and their families would be supported so that they could travel to them; the Commonwealth War Graves Commission, established in 1917, worked (and indeed continues to work) hard to preserve the sites for all and in particular for those soldiers whose relatives could not afford multiple visits or sustained upkeep.$^{64}$ The famed poet-soldier's mother was, instead, afforded opportunities to personalize proximate and distant public memorials to her son. She contributed to the development of the public myth, and to establishing him as a saleable, melancholic but ultimately consoling symbol of youth in war. This, in turn, fed into broader discussions and practices that standardised the ways in which the collective war dead were invoked and remembered.

\section{CONCLUSION}

Melancholia has long been written about in Western literature. In The Anatomy of Melancholy, first published in 1621, Robert Burton writes of the 'care, sorrow, and anxiety, obfuscation of spirits, agony, desperation and the like' specific to women. (He assumed these feelings emanated primarily from menstruation or 'amatory' passions. ${ }^{65}$ ) Mourning women like Mary Brooke, traditionally confined and often silenced, dismissed, and ignored, might have reason to be particularly inclined to a state of passive frustration, particularly when they found themselves confronted with the grim reality of life after war, be they members of societies identifying as righteous or guilty, 'victors' or 'losers'.

War, mourning, and melancholia are closely linked, and ever-repeating. Writing about London in the wake of VJ Day, Feigel observes that, 'after the intensity of wartime life, the post-war period seemed grey and slow. Moments out of time, suspended between past and future, gave way to a continuum in which life was measured once again in years and decades rather than in days and weeks ${ }^{66}$ The feeling of contemplative depression permeates, moving across national boundaries: in her comparative study of post-Second World War Germany and Britain, Julia Vossen argues that works produced by writers in both the victorious and defeated nations articulated a profound melancholia born of a combination of horror and reflection. ${ }^{67}$

We read artistic expressions that respond to conflict as part of a longer conversation about the lingering effects of violence and loss; through 
their work, artists probe these cultural ruptures in order to extend our understanding of the costs of conflicts for individuals and societies. Winter brings his study Sites of Memory, Sites of Mourning: The Great War in European Cultural History (1995) to a close by drawing a link between the writings of the Franco-Polish-Belarussian poet-soldier Guillaume Apollinaire, who died in 1918, and the German-Jewish philosopher and essayist Walter Benjamin, who died in 1940, to draw attention to the continuous push and pull between 'abstract images' and 'older symbolic forms' ${ }^{68}$ These war writers and their diverse creative expressions, born of collective and individual melancholia, are forever in dialogue, forming bridges that reveal the extent of repeated traumas.

Life writing about war can link the personal and the public in compelling and unexpected ways, and take on a variety of forms. Compounding loss and trauma is, perhaps, made more comprehensible when viewed through a single lens, applied to a specific period or moment in time. Mary Brooke suffered the deaths of her husband and elder son from illness, and subsequently her two younger sons during the First World War. Her experience of the role of survivor was unique and personal. But in contributing to, or in some cases asserting control of her poet-soldier son's life narrative, she was able to express, and ultimately fix in public her philosophical and aesthetic ideal of sacrifice, grief and melancholia. Her role in the process of cultural commemoration was active, practical and ultimately lasting, defying potentially passive constructions of-particularly gendered-melancholia.

At the same time, the war writer's lens can also be widened to take in collective cultures and extended periods: Europe's and the wider world's continuous cycling through 'contained' and global conflicts in the first half of the twentieth century, and (sadly) carrying on into the present day, and for the foreseeable future. Communal participation in public art in societies, as they identify ways to contend with the war and its dead, is an important part of official forms of recovery and reconstruction. In On the Natural History of Destruction (1999), W. G. Sebald includes a characteristically vague illustrative image of humans in contemplation. It shows a crowd of people, perhaps in a public building or church, facing in the same direction towards a fixed point that cannot be identified. Young and middle-aged women proliferate in the crowd; their faces are turned reflectively towards the unknown object of attention. Some women are seated, some are kneeling. The photograph conveys, all at once, a sense of individual reflection undertaken in a communal setting. The implication from the text is that they are attending a public concert. Sebald writes of such audiences in the immediate post-war ruins, speculating about their emotions: 'eyes shining as they listened to 
the sound of music rising in the air all over the country [...] moved by a sense of gratitude that they had been saved'? Or were they, at least to some extent, revelling in the art while taking a 'perverse pride' in their common suffering? ${ }^{69}$

Rupert Brooke's 'War Sonnets' captured a particular abstracted response to conflict, suffering and death that bridged nineteenth- and twentieth-century poetic lexicons. Although his strain of poetry and writing was, in part, repudiated by fellow British soldier-writers like Charles Sorley, Siegfried Sassoon, Robert Graves and many others, his poetry has remained a consoling touchstone for grieving families, and for a variety of institutions charged with framing loss in war in safe and familiar terms. ${ }^{70}$ His mother, Mary Brooke, played a key role in cultivating his lasting public image; this remained her primary focus until her death in $1931 .{ }^{71}$ Her experience of gendered melancholia ${ }^{72}$ produced its own creative responses to the death of her son, the nation's poetsoldier, which took the form of epitaphs and monuments. While her expressions of loss might not rise to the level of what has traditionally been described as war art or literature, they do in their way establish their own dialogue with past, present and future forms of memorial expression.

\section{ACKNOWLEDGMENTS}

This article has been made possible as a result of funding from the European Research Council (ERC) for the project 'Beyond Enemy Lines: Literature and Film in the British and American Zones of Occupied Germany, 1945-1949' [FP7/2007-2013; grant agreement No. 335101].

\section{WORKS CITED}

Alexievich, Svetlana. Boys in Zinc. Trans. Andrew Bromfield. London: Penguin, 2017. Brooke, Rupert. 1914 and Other Poems. London: Sidgwick and Jackson, 1915.

Burton, Robert. The Anatomy of Melancholy. New York: New York Review of Books, 2001.

Dickens, Charles. 'Trading in Death.' Household Words VI:140 (27 November 1852) 241-245.

Feigel, Lara. 'Kind of blue: Making sense of melancholia.' Financial Times, 22 September 2017, https://www.ft.com/content/88f5019c-9e16-11e7-8b50-0b9f565a23e1. Date accessed: 15 August 2017.

Feigel, Lara. The Love-charm of Bombs: Restless Lives in the Second World War. London: Bloomsbury, 2013.

Feigel, Lara and John-Paul Stonard. Melancholia: A Sebald Variation. London: Inigo Rooms, Somerset House, 21 September to 10 December 2017.

Gillis, John R. (ed.). Commemorations: The Politics of National Identity. Princeton: Princeton University Press, 1994. 
Gregory, Adrian. The Last Great War: British Society and the First World War. Cambridge: Cambridge University Press, 2008.

Freud, Sigmund. On Murder, Mourning and Melancholia. Trans. Shaun Whiteside. London: Penguin, 2005.

Hassall, Christopher. Edward Marsh, Patron of the Arts: A Biography. London: Longmans, Green and Company, 1959.

Hassall, Christopher. Rupert Brooke. London: Faber and Faber, 1964.

Hynes, Samuel. A War Imagined: The First World War and English Culture. London: Pimlico, 1990.

Jalland, Pat. Death in the Victorian Family. Oxford: Oxford University Press, 1996.

Keynes, Geoffrey (ed.). The Letters of Rupert Brooke. New York: Harcourt, Brace and World, 1968.

Marsh, Edward (ed.). The Collected Poems of Rupert Brooke. London: Sidgwick and Jackson, 1918.

Marwick, Arthur. The Deluge. London: Palgrave, 2006.

Miller, Alisa. 'England and France in the First World War: Translating the Myth of the Poet Soldier.' In: Nicolas Bianchi and Toby Garfitt (eds.), Writing the Great War/Comment écrire la Grande Guerre? Oxford: Peter Lang, 2017, 49-64.

Miller, Alisa. Rupert Brooke in the First World War. Clemson: Clemson University Press, 2018.

Morley, John. Death, Heaven and the Victorians. London: Studio Vista, 1971.

Mosse, George L. Fallen Soldiers: Reshaping the Memory of the World Wars. Oxford: Oxford University Press, 1990.

Nora, Pierre. Les lieux de mémoire. Paris: Gallimard, 1984-1992.

Papers of Rupert Chawner Brooke. Cambridge: King's College.

Sebald, W. G. On the Natural History of Destruction. Trans. Anthea Bell. London: Penguin, 2003.

Strange, Julie-Marie. Death, Grief and Poverty in Britain, 1870-1914. Cambridge: Cambridge University Press, 2005.

Taylor, Lou. Mourning Dress: A Costume and Social History. London: Routledge, 1983.

Todman, Dan. The Great War, Myth and Memory. London: Hambledon and London, 2005.

Vossen, Julia. Transnational Rubble Literature: A Comparative Study of German and British Post-War Texts. PhD Thesis, King's College London, 2018.

Waller, Philip. Writers, Readers and Reputations: Literary Life in Britain, 1870-1918. Oxford: Oxford University Press, 2006.

Winter, Jay. Sites of Memory, Sites of Mourning: The Great War in European Cultural History. Cambridge: Cambridge University Press, 1995.

\section{ABOUT THE AUTHOR}

Alisa Miller is based at the Royal Military Academy Sandhurst, where she is a Senior Lecturer in War Studies; she is also a Visiting Research Fellow in the Centre for Life-Writing Research at King's College London. From 2016 to 2020, she served as Research Fellow in the English Department at King's College London, working on the ERC-funded Beyond Enemy Lines and Ego-Media projects. Her research focuses on the comparative development of war cultures in twentieth and twenty-first century Europe and the United States, looking at how evolving literary networks - utilizing different forms of media and technology-influence political discourses and perceptions of violence. Her first book, Rupert Brooke in the First World War, was published by Clemson and Liverpool University Press in 2018. E-mail: Alisa.m.miller@kcl.ac.uk. 


\section{NOTES}

1 Jalland, Pat. Death in the Victorian Family. Oxford: Oxford University Press, 1996 (380).

2 For an excellent, sustained discussion of the evolution of dress in the period as it relates to elite and popular culture, Taylor, Lou. Mourning Dress: A Costume and Social History. London: Routledge, 1983.

3 Dickens, Charles. 'Trading in Death.' Household Words VI:140 (27 November 1852) (241-245).

4 Morley, John. Death, Heaven and the Victorians. London: Studio Vista, 1971 (12).

5 Idem (65).

6 Taylor, Lou, 1983 (52).

7 Morley, John, 1971 (18).

8 Strange, Julie-Marie. Death, Grief and Poverty in Britain, 1870-1914. Cambridge: Cambridge University Press, 2005 (200).

9 See, for example, Gillis (ed.). Commemorations; Mosse, Fallen Soldiers; Nora (ed.). Les lieux de mémoire; and Todman. The Great War, Myth and Memory for extensive discussion about the figure of dead soldier as a sanctified nationalist symbol.

10 The author served as Research Assistant on the 2017 ERC-funded exhibition Melancholia: A Sebald Variation curated by Lara Feigel and John-Paul Stonard, which provides the basis for some of the ideas about melancholia and war advanced in this article.

11 Marwick, Arthur. The Deluge. London: Palgrave, 2006 (82-83).

12 Winter, Jay. Sites of Memory, Sites of Mourning: The Great War in European Cultural History. Cambridge: Cambridge University Press, 1995 (49).

13 Hassall, Christopher. Rupert Brooke. London: Faber and Faber, 1964 (524-525).

14 Quoted in Feigel, Lara and John-Paul Stonard, 2017.

15 Huxley, Gervas. Quoted in Philip Waller, Writers, Readers and Reputations: Literary Life in Britain, 1870-1918. Oxford: Oxford University Press, 2006 (232).

16 Churchill, Winston. 'Death of Mr. Rupert Brooke.' The Times, 26 April 1915.

17 Brooke, Rupert. 'III. The Dead.' 1914 and Other Poems. London: Sidgwick and Jackson, 1915.

18 Churchill's secretary, Edward Marsh, one of Rupert's closest friends and patrons, and Geoffrey Dawson, editor of the national paper of record, contributed to the drafting of this key section of the obituary; The Times staff writer Arthur Clutton-Brock worked with Marsh to compile the factually-orientated, less romantic section of the death notice.

19 Churchill, Winston, 1914.

20 Contemporary Review, December 1915.

21 Free Thinker, 16 May 1915.

22 Murray, Gilbert. Cambridge Magazine, 1 May 1915.

23 Westminster Gazette, 1 May 1915.

$24 \mathrm{RCB} / \mathrm{Xf} / 11$, Mary Brooke, Sales Figures to 31 December 1920.

25 For an extended discussion of the mechanisms that enabled Rupert Brooke's myth and celebrity, and of its broader cultural role during the First World War, see Alisa Miller. Rupert Brooke in the First World War. Clemson: Clemson University Press, 2018. For a specific case study of how the myth was translated across national boundaries, and the actors who enabled this, see Alisa Miller. 'England and France in the First World War: Translating the Myth of the Poet Solider.' In: Nicolas Bianchi and Toby Garfitt (eds.), Writing the Great War/Comment écrire la Grande Guerre? Oxford: Peter Lang, 2017 (49-64).

26 Jalland, Pat, 1996 (380).

27 Strange, Julie-Marie, 2005 (260).

28 Freud, Sigmund. On Murder, Mourning and Melancholia. Trans. Shaun Whiteside (204). 
29 Winter, Jay, 1995 (115).

30 Rupert Brooke to Frances Cornford, 10 June 1914, In: Geoffrey Keynes (ed.), The Letters of Rupert Brooke. New York: Harcourt, Brace and World, 1968. (592).

31 Hassall, Christopher, 1964 (70).

32 Idem (375).

33 Rupert Brooke to Edward Marsh, 9 March 1915, in Keynes, LORB (669).

34 Hassall, Christopher, 1959 (522).

35 Rugby Observer, 18 June 1915.

$36 \mathrm{RCB} / \mathrm{Xf} / 4$, Poem included with Laurence Binyon to Mary Brooke, 31 March 1917.

37 I. S. Galovneva. 'Statement in Court.' Reprinted in Svetlana Alexievich, Boys in Zinc. Trans. Andrew Bromfield (244).

38 Idem (246).

39 Hassall, Christopher. Edward Marsh, Patron of the Arts: A Biography. London: Longmans, Green and Company, 1959 (341).

40 Edward Marsh to Mary Brooke, 10 May 1916, quoted in idem (391).

41 Mary Brooke to Marsh, May 1916, quoted in idem (387).

42 Marsh to Frank Sidgwick, quoted in idem (385).

43 Mary Brooke. Introductory note to Edward Marsh, The Collected Poems of Rupert Brooke. London: Sidgwick and Jackson, 1918.

44 Times Literary Supplement, 8 August 1918.

45 Cambridge Review, 22 November 1918.

46 Oxford Magazine, 22 November 1918.

47 Hynes, Samuel. A War Imagined: The First World War and English Culture. London: Pimlico, 1990 (277).

48 For an extended discussion of critical responses to the popular Brooke myth that emerged in the spring of 1915 and continued to grow throughout the war, see Miller, Alisa, 2018 (193-204).

49 Hynes, Samuel, 1990 (277).

50 Brooke. 'V. The Soldier.' 1914 and Other Poems.

51 Gregory, Adrian. The Last Great War: British Society and the First World War. Cambridge: Cambridge University Press, 2008 (251).

52 Idem (252-253).

53 Winter, Jay, 1995 (98).

54 Hassall, Christopher, 1964 (527).

55 Feigel, Lara. 'Kind of blue: Making sense of melancholia.' Financial Times, 22 September 2017: https://www.ft.com/content/88f5019c-9e16-11e7-8b50-0b9f565a23e1. Date accessed: 15 August 2017.

56 RCB 11/Xe/2, Mary to Ambassador Elliot, 2 May 1917.

$57 \mathrm{RCB}$ Xd/3, Robert Whitelaw to Mary Brooke.

58 For discussion of the limitations of Victorian epitaph writing as a genre, see Morley, John, 1971 (43-44; 52-53).

59 RCB Xd/3, Robert Whitelaw to Mary Brooke.

60 Morley, John, 1971 (101).

$61 \mathrm{RCB}$ 11/Xe/I, Elliot to Marsh, 13 June 1915.

$62 \mathrm{RCB} 11 / \mathrm{Xe} / 2$, E. B. Hoare to Elliot, 16 April 1917.

$63 \mathrm{RCB}$ 11/Xe/2, Elliot to Mary, 4 June 1917.

64 For a full discussion of debates around what to do with the war dead and the role memorials played in the cultural management of grief and mourning, see Winter, Jay, 1995 (78-116).

65 Burton, Robert. The Anatomy of Melancholy. New York: New York Review of Books, 2001 (415). 
66 Feigel, Lara. The Love-charm of Bombs: Restless lives in the Second World War. London: Bloomsbury, 2013 (291).

67 Vossen, Julia. Transnational Rubble Literature: A Comparative Study of German and British Post-War Texts. PhD Thesis: King's College London, 2018.

68 Winter, Jay, 1995 (228-229).

69 Sebald, W. G., 2003 (43-45).

70 For further discussion of Brooke's persistent popularity after his death, see Miller, Alisa, 2018 (1-10; 223-226).

71 See Hassall, Christopher, 1964 (519-533).

72 For a concise discussion of contemporary gendered melancholia and the various artists-working across a variety of media-whose work speaks to this persistent state, see Feigel, Lara, 2017. 